Patryk Zenon Angielczyk

Uniwersytet w Białymstoku

E-MAIL: patryk.angielczyk9o@gmail.com

\title{
Homo crudelis w dobie Internetu
}

\section{STRESZCZENIE}

Powszechny dostęp do Internetu wiąże się ze wzrostem liczby patologicznych aktywności w Sieci. Autor przedstawia zjawisko patostreamingu - emitowanych na żywo demoralizujących zachowań, aktów agresji werbalnej i przemocy fizycznej, których celem jest zyskanie popularności mierzonej oglądalnością oraz korzyściami finansowymi. Patostream został ukazany w perspektywie historycznej jako odwieczne zapotrzebowanie na okrucieństwo oraz jako przejaw ekshibicjonizmu i narcyzmu w kulturze mediów wizualnych.

SŁOWA KLUCzOWE: Internet, patostream, okrucieństwo, ekshibicjonizm, narcyzm

\section{Wprowadzenie}

Upowszechnienie technologii informacyjnych sprawiło, że nie sposób już wyobrazić sobie funkcjonowania złożonych struktur państwowych i instytucji społecznych bez Internetu. Na rynek pracy weszło pokolenie, dla którego dostęp do Sieci jest czymś oczywistym, standardem prywatnej i zawodowej aktywności. Jednak przestrzeń Internetu jest jak nowo odkryty kontynent, oferujący możliwości nieograniczonej ekspansji. Jest światem, w którym nie skodyfikowano obowiązujących w nim zasad, a to z kolei sprzyja różnego rodzaju nadużyciom. Bezpośrednią inspiracją do napisania artykułu była dyskusja społeczna, która toczyła się w Polsce w związku z wyrokiem sądu w sprawie polskich patostreamerów (por. Suchodolska, 2018; Wierciński, 2019).

Artykuł jest próbą zrozumienia źródeł i fenomenu popularności zjawiska, jakim jest patostreaming w Sieci. Tekst składa się z trzech części. Wstęp zawiera wyjaśnienie pojęcia oraz kilka uwag na temat zmian społeczno-kulturowych związanych z „migracją” życia społecznego do Internetu. W części drugiej przedstawiam charakterystykę patostreamów, sposoby ich tworzenia i upowszechniania, interaktywny charakter transmisji oraz związane z tym uwarunkowania ekonomiczne. Część trzecia stanowi próbę znalezienia odpowiedzi na pytanie: jakie są psychospołeczne uwarunkowania determinujące zachowania twórców i odbiorców patostreamów? Czy źródłem patologii są 
technologie informacyjne, ludzkie zapotrzebowanie na okrucieństwo, czy może, właściwe kulturze mediów wizualnych, ekshibicjonizm i narcyzm wspierane filozofią zysku? Całość tekstu stanowi zachętę do refleksji nad przedstawionymi zagadnieniami.

Pojęcie „patostream” zostało złożone ze słów: pato od 'patologia' i stream (ang. strumień), które jest określeniem transmisji, cyfrowego przekazu (strumień informacji). Patostreamy to filmy nagrywane na żywo (bez scenariusza i innych cech filmu fabularnego) przez patostreamera wytwórcę, są swoistym reportażem dokumentującym patologiczną rzeczywistość.

Zastanawiające jest, że mimo stosunkowo wysokiego poziomu życia młodego pokolenia, kultury społecznej w naszym kraju oraz edukacji w zakresie przeciwdziałania przemocy, tak prymitywne i wulgarne treści znajdują rzeszę licznych odbiorców. Niekiedy zaś bawią i fascynują widzów.

W dobie rozwoju technologicznego i wzrastającego znaczenia Internetu w kontaktach międzyludzkich przyzwolenie na filmowanie i upublicznianie realnych aktów brutalnej i bezmyślnej agresji podważa obowiązujące normy współżycia społecznego, staje się zachętą do naśladownictwa - patostreaming jest formą zarabiania pieniędzy, nie wymaga specjalistycznej wiedzy i umiejętności, jedynie posiadania komputera z dostępem do Sieci. Niebezpieczeństwo demoralizacji dzieci i młodzieży - to tylko jedno z wielu zagrożeń wynikających z popularności patostreamów.

Jak sądzę, ważną częścią problemu jest fakt, że rodzice, nauczyciele i wychowawcy mają ograniczoną świadomość zagrożeń związanych z korzystaniem $\mathrm{z}$ Internetu (Baran $\mathrm{i}$ in., 2016). Z badań przeprowadzonych w marcu i kwietniu 2019 roku na zlecenie Fundacji Dajemy Dzieciom Siłę w grupie 400 osób w wieku 13-15 lat wynika, że aż 37\% uczestników badania ogląda patotreści, $5 \%$ odmówiło odpowiedzi na pytanie, $48 \%$ słyszało o patostreamingu, a tylko $12 \%$ zetknęło się z tym terminem po raz pierwszy, wypełniając ankietę. Dla większości dorosłych patostreamy mogą wydawać się czymś szokującym i niezrozumiałym, dla wielu nastolatków są czymś normalnym - formą internetowej rozrywki. Dzieje się tak, ponieważ pokolenie rodziców i pokolenie dzieci wychowało się i żyje w innych rzeczywistościach. Na przestrzeni ostatnich 30 lat dokonała się radykalna zmiana nie tylko polityczno-gospodarcza, ale zwłaszcza społeczno-kulturowa.

Pierwsze połączenie internetowe w Polsce miało miejsce 17 sierpnia 1991 roku i było związane z powstaniem na Uniwersytecie Warszawskim NASK (Naukowej i Akademickiej Sieci Komputerowej). Oficjalnie Polska została podłączona do Sieci 20 grudnia tego samego roku. W ciągu kolejnych lat przestrzeń Internetu stała się ważnym elementem w życiu wielu ludzi, stwarzając olbrzymie 
możliwości w komunikacji społecznej. Komputeryzacja niesie jednak problemy społeczne, psychologiczne, organizacyjne czy ekonomiczne. Szkodliwych, często niebezpiecznych, noszących znamiona przestępstwa zjawisk w Sieci jest bardzo dużo. Problem cyberprzemocy został uznany przez rząd RP za poważną kwestię społeczną (NIK, 2017). Sposoby przeciwdziałania cyberprzemocy zostały włączone do programów edukacyjnych w ramach rządowej strategii „Bezpieczna i przyjazna szkoła” realizowanej od 2008 roku, obecnie pod nazwą „Bezpiecznat” (Walendzik i Wilkosz, 2018).

Przeprowadzono szereg badań na temat pozytywnej bądź negatywnej roli Internetu w życiu człowieka (Błachnio, 2007; Tanaś, 2016; Płatek, 2017). $\mathrm{Z}$ większości z nich wynika, że samo korzystanie z Internetu bezpośrednio nie prowadzi do negatywnych skutków w interakcjach społecznych. Jednak w określonych warunkach Internet może działać jako namiastka innych rodzajów aktywności człowieka. Coraz więcej działań ludzkich przenosi się do wymiaru wirtualnego. Dla coraz większej liczby użytkowników Internetu bardziej realne i ważne jest to, co dzieje się na ekranie komputera niż w ich najbliższym otoczeniu. Tak więc odbiorca nie odróżnia przestrzeni realnej od wirtualnej (Górka, 2017, s. 16-17).

\section{Charakterystyka patostreamów}

Patostream może wydawać się wypaczoną formą telewizyjnego reality show. Twórcy nagrań często postrzegają siebie jako artystów - szok jest w końcu przeżyciem estetycznym (Siedlanowski, 2018). Nie wdając się w spory o definicję sztuki, można stwierdzić, że w tym kontekście proces twórczy sprowadza się do włączenia przez patostreamera kamery internetowej, która rejestruje zdarzenia $\mathrm{z}$ nim samym $\mathrm{w}$ roli głównej oraz osobami mu towarzyszącymi. Przed kamerą odgrywane są różne aktywności, np. rozmowy, monologi, „dyskusje” między uczestnikami - „gośćmi” patostreamera, bicie, kopanie, obrażanie rozmówców lub osób postronnych itp., wszystko okraszone wulgaryzmami, obelgami, słowami obscenicznymi. Ten przekaz „idzie” na żywo przez wiele godzin w Sieci. Działalność taka nie wymaga posiadania koncesji, wozów transmisyjnych i specjalistycznego sprzętu - komputer z kamerą i dostępem do Internetu w zupełności wystarczy.

Patostreaming jako termin nie figuruje w anglojęzycznej literaturze przedmiotu. Pojęcie to pojawiło się wśród polskich użytkowników Sieci i zostało przejęte przez badaczy tego fenomenu. Warto zauważyć, że samo zjawisko dość szybko znalazło się w kręgu zainteresowań środowisk analizujących zagrożenia wynikające z propagowania okrucieństwa w Internecie (Kmieciak-Goławska, 2018; Bek i Popiołek, 2019) oraz naukowców obserwujących trendy 
kulturowe (Wojtyna, 2019). Niestety, wiedza na jego temat rzadko trafia do szerokiego kręgu odbiorców. Tymczasem nazwiska (nicks) producentów, takich jak: Rafonix, Gural, Rafatus, Daniel Magical czy Medusa zazwyczaj niewiele mówią dorosłym użytkownikom Sieci. Natomiast 37\% nastolatków doskonale zna produkcje tych patostreamerów. Nie sądzę, by patostream był tylko chwilową modą, uważam, że przekształci się w inne zjawisko, uderzające jeszcze większą brutalnością i cynizmem ze względu na narastające „zapotrzebowanie społeczne” na tego typu „rozrywkę". Według statystyk ze strony Patostreamy.com stale rośnie liczba oglądających, pojawiają się kolejni patostreamerzy. Jest to problem istotny społecznie ze względu na jego skalę i ogromne nasycenie agresją. Niebezpieczeństwo, jakie niosą patostreamy jest nagłaśniane w mediach, czego przykładem mogą być: program stacji TVN „Uwaga! Dzieci w Sieci” oraz program „Alarm!” autorstwa dziennikarzy TVP1. Ósmego lipca 2019 w Ministerstwie Cyfryzacji odbyło się spotkanie dotyczące owego problemu. Udział wziął w nim Adam Andruszkiewicz, wiceminister cyfryzacji, a także przedstawiciele NASK, operatorów internetowych, Komendy Głównej Policji, biura Rzecznika Praw Dziecka oraz biura Rzecznika Praw Obywatelskich. Celem spotkania było powołanie grupy roboczej ds. walki z patostreamami i cyberprzemocą. Jej zadaniem będzie przygotowanie regulacji prawnych, które pozwolą na skuteczniejsze zwalczanie tego zjawiska.

Kolejne zagrożenie związane $\mathrm{z}$ patostreamingiem polega na tym, że dotychczas, w przypadku podobnych produkcji filmowych, nie było interakcji między nadawcą a odbiorcą. Dziś możliwy jest wpływ obustronny. Podczas wyświetlania patostreamu odbiorca (oglądający) może poprzez odpowiedni komentarz lub zaoferowanie określonej zapłaty (czasem jest to bardzo mała kwota) wpłynąć na osobę transmitującą, zachęcić ją do podjęcia (modyfikacji) zadanego działania bądź wyperswadować eskalację drastycznych poczynań. $\mathrm{W}$ związku z tym odbiorca ma poczucie współtworzenia (autorstwa) toczących się wydarzeń. Patoblogerzy, patostreamerzy są autorami amatorskich filmików (najczęściej bohaterami są oni sami, bywa że towarzyszą im inne osoby) zamieszczanych zazwyczaj w serwisie You Tube. Ukazują patologiczne zachowania: upijanie się do nieprzytomności, wyzwiska, awantury, bójki, poniżanie, podpalanie kolegów, wymioty, załatwianie się do wiaderka, gry, którym towarzyszą niewybredne komentarze i grubiańskie wyrażenia itp. (Pato)kreatywność jest ogromna. Zwykle przekazy nie są zgłaszane administratorowi, co jest niezgodne $\mathrm{z}$ regulaminem serwisu. Materiały oglądają tylko chętni, zatem patostreamerzy praktycznie są bezkarni. Platforma You Tube deklaruje walkę $\mathrm{z}$ tego typu zachowaniami, jednak jedynym sposobem 
na ograniczenie działalności patostreamerów jest oznaczenie materiałów jako treści dostępnych wyłącznie dla osób dorosłych lub złożenie doniesienia do odpowiednich organów państwowych. Nie jest to jednak skuteczne zabezpieczenie, a tym bardziej ochrona młodego odbiorcy. Ograniczenie wiekowe to w znacznie większym stopniu zachęta i reklama niż bariera.

Sam fakt popularności patostreamów mierzonej ilością wyświetleń wystarcza, by różne firmy zamieszczały swoje reklamy jako materiał towarzyszący relacjom patostreamerów. Obserwacje nadzoru pedagogicznego pokazały, że treści te są doskonale znane uczniom klasy V i starszym. Zdarzają się sytuacje, gdy wiek „patostreamowej inicjacji” (głównie za przyczyną starszego rodzeństwa) był niższy niż 10 lat (Siedlanowski, 2018). Patostream ma magiczną moc przyciągania. Młodzi ludzie uczestniczą w nim jako odbiorcy interaktywnie (pisanie komentarzy i przesyłanie napiwków), angażując się tym samym w patologiczne działania.

Próby walki ze zjawiskiem podejmują liczni użytkownicy Internetu, konsekwentnie zgłaszając popełniane nadużycia administratorom stron i serwisów społecznościowych, co niekiedy skutkuje zablokowaniem konta osoby zamieszczającej patotreści. Jednak trudnością reagowania na patostream jest to, że nagranie po zakończeniu przekazu nie jest zapisywane na kanale, odbiorca ogląda patostream tylko jeden raz, a więc nie można go zablokować. Ślady streamu pozostają w postaci tzw. shotów, czyli kopii, zrzutów ekranowych. Odbiorcy transmisji nagrywają „,co lepsze kawałki” z przekazu i umieszczają na swoich kanałach. Stąd rozchodzą się do innych odbiorców w tysiącach odsłon. Odpowiednio duża ilość wyświetleń, przeplatanych reklamami, to konkretny dochód patostreamerów. Kontrowersyjny, skandaliczny film oraz jego autor/bohater często staje się obiektem hejtu. Nie stanowi to problemu dla patostreamera, ponieważ wówczas przekaz robi się bogatszy w emocje i wulgaryzmy. Napędza koniunkturę i zwiększa oglądalność. Oczywiście najwięcej zarabiają na swoim procederze sami patostreamerzy, bo taki jest główny cel ich działania. Pieniądze otrzymują od platformy streamingowej, ale też od widzów, którzy w trakcie transmisji mogą wpłacać „donejty”, czyli napiwki. Zdarza się, że „widownia”, w myśl zasady „płacę - wymagam”, stawia coraz bardziej ekstremalne żądania, zmuszając „aktorów” do przekraczania granic, prowokując do bójek do krwi i awantur.

Redaktorzy TVN w programie „Uwaga!” podjęli problem patostreamów, rozmawiając z jednym z twórców, Rafatusem. Przekonywał widzów, że tworzony przez niego film jest kontrowersyjną sztuką nowoczesną, w której on jako aktor gra określoną rolę. Sugerował, że skoro przez rok emituje patostreamy, stał się po części artystą - nie jest więc prawdą, że działalność patostrea- 
merów jest patologią. Podobnie oceniają swoją działalność inni patoblogerzy, nie widząc nic złego w prezentowanych filmach. Jest to jeden z powodów, dla którego sporadycznie lub wcale nie reaguje na to zjawisko policja. Skoro nie ma zgłoszenia przestępstwa, więc nie ma podstawy do interwencji. Jedynie naruszenie prawa pociąga za sobą interwencję organów ścigania $\mathrm{z}$ urzędu. Naruszeniem może być np. zachęcanie do czynów karalnych, namawianie nieletnich dziewczynek do rozbierania się przed kamerą albo pogwałcenie miru domowego itp. Jednak sądowe wyroki za patostreaming wciąż należą do rzadkości. Tymczasem niektórzy patostreamerzy w trakcie kilkunastominutowego przekazu zarabiają od kilku do kilkunastu tysięcy złotych. Najbardziej popularni mają ćwierć miliona subskrybentów i dodatkowe zyski płynące z reklam. Jest to ogromna zachęta dla naśladowców. Szybki zarobek i perspektywa popularności sprawiają, że liczba patostreamerów stale wzrasta. Większość z nich (czy też kolekcjonerów shotów) to nastolatki, które chcą zarabiać pieniądze bez większego wysiłku. Mimo że nie od razu osiągają sukces, to wierzą, że uda im się zainteresować licznych odbiorców szczególnie drastycznymi scenami i wulgarnymi słowami w filmach. W konsekwencji obrazy są coraz ostrzejsze, sceny coraz okrutniejsze, gdyż to zapewnia coraz wyższy poziom ekscytacji, a przez to dużą liczbę odbiorców. W 2018 roku pojawiła się, profesjonalnie prowadzona, strona internetowa charakteryzująca polski patostream (www.patostream.pl). Zawiera m.in. statystyki kanałów, rekordy oglądalności, wskazuje najlepsze strony zawierające shoty, co dodatkowo sprzyja normalizacji tego zjawiska, wzmacniając przekonanie, że patostream jest tylko jedną z wielu form rozrywki.

\section{Technologie informacyjne jako źródło nowych patologii}

Rozwój technologiczny, jaki obserwujemy w minionych kilku dekadach, upowszechnienie się nowych technologii informacyjnych, twórcza inwencja $\mathrm{w}$ ich wykorzystaniu są przyczyną zmiany zachowań komunikacyjnych i społecznych użytkowników Sieci. Rodzi to problemy, jakie jeszcze niedawno nie istniały (por. Błachnio, 2007; Tanaś, 2016; Płatek, 2017).

W roku 1977 Ken Olson, prezydent Digitalu, był zdania, że: „Nie ma żadnego powodu, aby każdy człowiek posiadał w swym domu komputer” (za: Siedlanowski, 2018). Kiedy komputer "trafil pod strzechy” nie przewidywano nieskończonych możliwości jego zastosowań: dobrych i złych. Zastosowanie komputera, Internetu ułatwiło życie człowiekowi, pomagając mu $\mathrm{w}$ wielu czynnościach codziennych, pracy, kontaktach interpersonalnych, ale treści i możliwości współczesnych mediów niosą za sobą ryzyko deprawacji, przyczyniają się do rozwoju i wzmocnienia patologii. Pokolenie użytkowników Sieci, 
by przetrwać, będzie musiało stawić czoła wszystkim negatywnym zjawiskom pojawiającym się w wirtualnej przestrzeni (Jędrzejko i Morańska, 2014).

Badacze technologii cyfrowych M. Prensky i G. Small (2001) mówią o pełnowymiarowym pokoleniu ludzi rozwijających się w środowisku maksymalnego nasycenia nowymi technologiami cyfrowymi. Nazywają ich cyfrowymi tubylcami, ponieważ żaden $\mathrm{z}$ nich nie zna świata, w którym nie byłoby komputerów, 24-godzinnych wiadomości, łatwo i wszędzie dostępnego Internetu oraz telefonów komórkowych. Drugie pokolenie "cyfrowych imigrantów" ma kłopoty ze zrozumieniem języka mediów cyfrowych i często izoluje się od świata wirtualnego w mediach internetowych. Niewątpliwie pojęcie pokolenia w kontekście użytkowników Sieci jest trochę inne niż określona genealogicznie czy metrykalnie grupa ludzi, która ma wspólne doświadczenia życiowe.

Szybkość i różnorodność zmian sprawiają, że pełnoletni użytkownicy technologii cyfrowej, doskonale obeznani ze światem informatyki, a użytkownicy sieci w wieku np. 12-15 lat to dwie, mocno różniące się grupy. Obniża się wiek „inicjacji informatycznej”, z urządzeń mobilnych (smartfon, tablet), z zasobów Internetu korzystają już przedszkolaki; stale wydłuża się czas ciągłego dostępu do Sieci (ok. 30\% nastolatków pozostaje w Sieci bez przerwy, niezależnie od miejsca pobytu, a 93,4\% codziennie korzysta z Internetu $\mathrm{w}$ domu (Siedlanowski, 2018). Jak wynika z raportu CBOS, zatytułowanego Dzieci i młodzież w Internecie - korzystanie i zagrożenia z perspektywy opiekunów, z 2015 roku, ówcześni absolwenci gimnazjum i uczniowie rozpoczynający edukację w szkole podstawowej mieli już bogatsze doświadczenia korzystania z technologii informatycznych. Uczniowie na pierwszym etapie edukacyjnym, mający za sobą tysiące godzin spędzonych przy komputerze, smartfonie czy tablecie, pierwsze doświadczenia korzystania ze smartfonu czy tabletu zdobywają już na etapie przedszkola. Dzięki temu przewyższają umiejętnością korzystania z Internetu swoich kolegów z wyższych etapów kształcenia w szkole podstawowej.

Na przekór temu postępowi należy stwierdzić, że choć szybko zmienia się świat zewnętrzny, ludzka natura podlega stałym prawom. Tempo ewolucji jest bardzo powolne, w odróżnieniu od szybkości postępu technicznego. Rozwój nauki dokonuje się bardzo szybko, gdy tymczasem nasze zmysły i mózgi rozwijają się zgodnie z dynamiką ewolucyjną i potrzebują dużo czasu na dostosowanie. Człowiek pozostaje niezmienny jako byt biologiczny. W związku z tym nosi w sobie stałe tęsknoty, tendencje, potrzeby psychofizyczne, a także „ciemne” stany i dążenia. Wiele wskazuje na to, że w konstrukcji psychicznej człowieka zawarty jest element mroczny, społecznie i moralnie nieakceptowalny, który objawia się poprzez swoiste zapotrzebowanie na okrucieństwo (por. Miller, 2008; Eco, 2018). 


\section{Patostream odpowiedzią na odwieczne zapotrzebowanie na okrucieństwo}

Homo crudelis - człowiek okrutny, preferujący obrazy telewizyjne i filmowe typu krwawej wendetty, gdzie „trup ścielę się gęsto, a krew leje się strumieniami”, to nie "wynalazek” XX wieku. Podobnie jak fascynacja przemocą, znajdująca odzwierciedlenie w grach, w których można wybrać narzędzia zabijania i swobodnie decydować o sposobach pozbawiania życia. Można sycić się widokami przemocy, krwi i cierpienia, upokarzania przeciwnika. Także w kinie i telewizji coraz częściej widzimy naturalistyczne obrazy umierania, detale ukazujące przerażające szczegóły, np. krew, wyprute wnętrzności, tułowie pozbawione członków itp. Większość przedstawicieli starszego pokolenia doznaje wówczas dyskomfortu i odwraca wzrok, natomiast młodzież zazwyczaj jest doskonale obeznana $\mathrm{z}$ takimi widokami (Krajewska, 2012; Wojtyna 2019). Najczęstszą reakcją jest więc śmiech lub obojętność (Cyrek, 2018).

Patostream ma swoje korzenie w telewizyjnych reality show, czy fabularyzowanych dokumentach, pokazywanych w czasie największej oglądalności. W świadomości wielu młodych użytkowników Internetu granica pomiędzy światem realnym i wirtualnym nie istnieje, zaś próg odporności na widok żenujących, szokujących czy makabrycznych sytuacji jest coraz wyższy (Groves $i$ in., 2006). Wiąże się to ze wzrostem tolerancji organizmu na adrenalinę, neuroprzekaźnik warunkujący pobudzenie organizmu w sytuacjach realnego, wyobrażonego lub obserwowanego zagrożenia. Stan pobudzenia może być odczuwany jako przyjemny lub pożądany, co przy długotrwałej ekspozycji sprawia, że ludzie są spragnieni intensywnych emocji i coraz mocniejszych wrażeń (Mellibruda, 2012; Lelonek-Kuleta, 2012). Znajdują je w Sieci, w której dość liberalnie traktuje się nawet skrajnie negatywne treści. Patologiczne skłonności i dewiacyjne pragnienia kształtuje dobrze znany mechanizm popytu i podaży. Patostreamowe transmisje $\mathrm{w}$ wersji soft można było wcześniej oglądać na medialnym rynku amerykańskim transmitowane w telewizji i Internecie - np. wrestling. W polskim show-biznesie jest to zdecydowanie nowość.

W historii naszej cywilizacji znajdujemy tak wiele przykładów okrucieństwa, że wydaje się ono nieodłączną częścią ludzkiej natury (por. Baummeister, 2001; Perry 2018). Krwawe walki o łup toczyły już hominidy (zgodnie z prawami natury), co zostało uwiecznione na liczących setki tysięcy lat naskalnych malowidłach. Jednak prawdziwe okrucieństwo i terror oraz wymyślne tortury pojawiły się wraz z rozwojem cywilizacji.

Przemoc jako taka jest wytworem kultury, wynikiem eksperymentu kulturowego. Jest stosowana w takim zakresie, na jaki pozwala aktualny stan sił destrukcyjnych 
[...]. Niszczenie i mordowanie jest dla człowieka jak gdyby oczywiste - od niepamiętnych czasów. Kultura pomaga mu w nadaniu tej umiejętności formy i kształtu. Problem nie tkwi w przepaści pomiędzy mrocznymi instynktami a obietnicami świata kultury, lecz w powiązaniu przemocy z kulturą (Sofsky, 1999, s. 226-227).

Liczba zamordowanych wrogów była znakiem siły i potęgi władców. Okrutnym torturom Asyryjczyków, krzyżowaniu przez Persów i Rzymian, egzekucjom na rynkach przyglądały się dziesiątki gapiów. Podobnie było w chrześcijańskiej Europie. Wykonywane publicznie wyroki śmierci, tortury były zwyczajem akceptowanym i lubianym (Moore, 2019). Były wymierzaniem kary, ale też miały funkcję rozładowywania emocji, dostarczały rozrywki obserwatorom. Stanowiły wyreżyserowane przedstawienia, które pokazywały, jak traktuje się zdrajców, jaki los spotyka przestępców lub wrogów porządku publicznego, czyli pełniły też funkcję dydaktyczną. Obserwatorom egzekucje dawały poczucie sprawiedliwości i zadośćuczynienie chęci odwetu. W starożytności morderstwa na wrogach, z których słynęli cesarze rzymscy - Kaligula, Tyberiusz czy Neron - były dokonywane na skalę masową i bardzo spektakularne ze względu na niewyobrażalne okrucieństwo. Dla starożytnych Rzymian oglądanie krwi, wysiłków i męki walczących na arenach gladiatorów oraz obserwowanie umierających skazańców było rodzajem teatru, symbolem władzy i podstawą funkcjonowania imperium, a jednocześnie realizacją zapotrzebowania na okrucieństwo (Siedlanowski, 2018).

Dopiero w połowie XVIII wieku rozpoczął się proces „redystrybucji ekonomii kary", która usunięta z przestrzeni publicznej miała być nie tyle dotkliwa i spektakularna, co nieuchronna. Okrutny „ceremoniał cofa się w cień i pozostaje już tylko kolejnym aktem proceduralnym lub administracyjnym” (Foucault, 2009, s. 11). Jednak późniejsze wieki nadal „doskonaliły” metody zadawania cierpienia, sposoby torturowania i zabijania. Zdaniem Zygmunta Baumana oświeceniowy racjonalizm i zdobycze epoki nowoczesnej przyczyniły się do eskalacji okrucieństwa, bowiem:

[...] regulacja racjonalna, uznana przez mentalność nowożytną za lek uniwersalny na to, co w ludzkim współżyciu niepożądane, okazała się bronią obusieczną. Dewaluując i paraliżując autonomię jaźni moralnej, łagodzi ona wprawdzie konflikt jaźn i z wymogami ładu ponadjednostkowego - ale zarazem - czyni ją bezbronną wobec zła, jakie ów właśnie ład kultywować może w imię postępu rozumu (Bauman, 1993, s. 118).

Holocaust nie był żadnym irracjonalnym wybuchem nie w pełni uświadomionych pozostałości barbarzyństwa. Ma swoje miejsce we współczesności na prawach pełnego obywatelstwa, co więcej - nie znalazłby takiego miejsca nigdzie indziej (Bauman, 1992, s. 40). 
Totalitaryzmy początków XX wieku, Auschwitz i sowieckie łagry, bestialskie tortury, masowe egzekucje przekroczyły wszelkie wyobrażenia o okrucieństwie, które prezentowali wyszkoleni oprawcy. To nie postęp techniczny, lecz rozwój moralny decyduje o jakości człowieczeństwa. Zdawać by się mogło, że doświadczenie wojen światowych, Holocaustu i masowych eksterminacji przyniesie wzrost świadomości i opamiętanie. Niestety, koniec wieku XX zanotował ludobójstwo w Rwandzie, czystki etniczne na Bałkanach, zaś drugie dziesięciolecie XXI wieku - wojnę w Syrii, okrucieństwo bojowników ISIS, zamachy terrorystyczne. Nowy wiek przyniósł także produkcję filmów, gier komputerowych, wszelkich innych form przekazu niosących wirtualne zabijanie, okrucieństwo, na co jest wciąż ogromne zapotrzebowanie.

Mimo moralnych wysiłków, mimo wszelkich prób poskromienia brutalności zło okazuje się nieprzemijalne. Naprawdę nieśmiertelne są najprymitywniejsze warstwy duszy (Sofsky, 1999, s. 226).

Philippe Charlier (2017), odwołując się do teorii psychologicznych i antropologicznych, twierdzi, że zdolność do nieuzasadnionego okrucieństwa jest cechą głęboko ludzką - człowiek okrutny tkwi w każdym z nas. Stanowi integralną, ciemną część ludzkiej natury. Zgodnie z nauczaniem Kościoła katolickiego natura ludzka jest skażona grzechem. Natura ludzka ,jest zraniona w swoich siłach naturalnych, poddana niewiedzy, otępieniu i władzy śmierci oraz skłonna do grzechu" (Katechizm Kościoła Katolickiego, art. 405). Badania prowadzone przez amerykańskiego psychologa społecznego K. Duttona (2014), zajmującego się problemami ludzi z zaburzeniami psychopatycznymi, wykazały, że w Muzeum Seryjnych Morderców we Florencji, najbardziej makabrycznym muzeum świata, stale jest mnóstwo odwiedzających, którzy powodowani są ciekawością, sensacją, głodem adrenaliny. Także w Polsce ogromnym zainteresowaniem cieszą się różnego rodzaju „sale tortur”. Dziś zmieniły się jedynie sposoby prezentacji okrucieństwa i odbiór społeczny. A nowe technologie dostarczyły supernowoczesnych - w niespotykanej dotąd skali - metod jego multiplikowania.

\section{Patostreaming jako przejaw ekshibicjonizmu i narcyzmu}

Magdalena Szpunar (2016) w swojej monografii Kultura cyfrowego narcyzmu dokonuje przeglądu teorii psychologicznych dotyczących zaburzeń osobowości ze spektrum narcyzmu. Ze względu na to, że obraz patostreamera doskonale wpisuje się $\mathrm{w}$ tworzony przez nie wizerunek narcyza, przedstawię pokrótce kilka $\mathrm{z}$ nich. Pierwsze teorie w nurcie psychoanalitycznym traktują 
narcyzm jako formę zaburzenia seksualnego. Alfred Binet w roku 1887 opisał pacjenta - fetyszystę, który doznawał podniecenia na widok białych fartuszków i zapasek. Nieco później Havelock Ellis wykorzystał imię Narcyza określając perwersję seksualną, w której jednostka traktuje samą siebie jak obiekt seksualny. Zygmunt Freud widział w narcyzmie podłoże wielu problemów psychicznych. Heinz Kohut przyczyn tej skłonności doszukiwał się w patologicznych relacjach dziecka z rodzicem, zaś Otto Kernberg interpretował zjawisko, odwołując się do stadiów rozwoju instynktów i konfliktów. Zygmunt Freud (1991; 2001) uznał, że zjawisko narcyzmu pozwala wyjaśniać: psychozy, zazdrość, sadyzm, ale także miłość. Twórca psychoanalizy określił narcyzm jako fazę niezbędną pomiędzy miłowaniem siebie a miłością do innych. Twierdził, iż każdy przychodzi na świat w stanie „całkowitego narcyzmu”. Według Freuda dramat jednostki narcystycznej polega głównie na tym, iż nie potrafi ona kochać nikogo, poza samą sobą. W klasycznej psychoanalizie narcyzm występuje $\mathrm{w}$ dwóch odmianach: ten pierwotny, który oznacza stan miłości do samego siebie, który poprzedza miłość do innego obiektu, i narcyzm wtórny, który oznacza ponowne skierowanie miłości do samego siebie. Freud narcyzm uznaje za niezbędną fazę między miłością do siebie a miłością do innych. Dokonuje tutaj rozróżnienia między introwersją a narcyzmem, który jego zdaniem stanowi podłoże zaburzeń określanych jako dementia praecox lub schizofrenia (Szpunar, 2016, s. 17).

Zygmunt Freud (1991) i Erich Fromm (1996) twierdzili, iż jednostki narcystyczne izolują się od świata zewnętrznego i w sposób patologiczny kierują się ku własnemu wnętrzu. Karen Horney $(1987 ; 1999)$ była jednak zdania, że człowiek narcystyczny pożąda innych, gdyż stanowią oni źródło jego oparcia i podziwu, które są niezbędne do codziennego funkcjonowania. Narcyzm może stanowić efekt neurotycznej tendencji do radzenia sobie z trudnościami poprzez wyolbrzymianie własnej wielkości. Widziany z tej perspektywy patostreaming staje się formą adaptacji jednostek niebędących w stanie sprostać potężnej presji kultury sukcesu.

Młody człowiek dość szybko przekonuje się, że nie jest najważniejszą osobą w otoczeniu, że równie ważni są inni ludzie, a domaganie się bezwzględnej atencji spotyka się z negatywnymi sankcjami otoczenia. Jak pisze Heinz Kohut (1997), przekonanie o własnej wspaniałości powinno wygasać u dziecka w wieku 2-4 lat, zaś idealizacja wyobrażenia rodziców powinna zanikać w wieku 4-6 lat. Zneutralizowane postacie prymitywnego „Ja” stanowią dwa podstawowe wyznaczniki napięcia, które wyznacza działanie między ideałami a ambicjami. Niestety nie zawsze dzieje się tak, że pierwotne formy wspaniałego "Ja" są zredukowane, a czasem bywają wzmacniane. Do narcy- 
stycznego uszkodzenia „Ja" może dochodzić z dwóch powodów. W pierwszym przypadku rodzice bezkrytycznie chwalą, nagradzają i hołubią wszystkie zachowania swojego dziecka. Rozwija ono cechy narcystyczne wtedy, gdy jest przeceniane i traktowane jako ktoś absolutnie wyjątkowy. Oczywiście każde dziecko powinno być przekonane i zapewniane o bezwarunkowej miłości rodzica. Narcyzm jednak rodzi się wtedy, gdy rodzice w sposób karykaturalny i zdeformowany przeceniają zdolności i umiejętności własnego dziecka, wmawiając mu, że jest najważniejszą/jedną z ważniejszych osób na świecie.

Magdalena Szpunar (2016), pisząc o narcyzmie w cyberprzestrzeni, przywołuje pojęcie „efektu trzeciej osoby”, który to efekt objawia się przekonaniem, że przekazy medialne silnie wpływają na innych ludzi, podczas gdy samemu jest się na nie odpornym. Oznacza to, że obcując w przejawami agresji i narcyzmu w Sieci, nieświadomie nasiąkamy tendencją do podobnych zachowań (Szpunar, 2016, s. 64; por. Groves i in., 2006). Jeśli media lansują celebrytów, przypisując im rolę ekspercką, promują ekshibicjonizm, zogniskowanie na samym sobie typowe dla self-brandingu. Powoduje to, że jednostki mogą traktować tego typu zachowania jako normę, bezmyślnie powielając propagowany wzorzec. To zapewne przyczynia się do wzrostu zachowań narcystycznych.

W Internecie występuje wiele blogów, stron WWW, których nikt nie odwiedza. Można takie media - blogi, strony WWW etc. - określać mianem mediów zerowych. W związku z tym nie jest ważne, by nadawać komunikaty online, ale by miały taką postać, aby znaleźć odbiorców. To szczególna dla nowych mediów cecha nadmiaru treści, które konkurują o uwagę adresatów. Ta „walka o bycie zauważonym” powoduje stosowanie rozmaitych zabiegów, włącznie z ekshibicjonistycznym upublicznianiem osobistych spraw i przemyśleń, dla zwrócenia uwagi na własny komunikat i wyeksponowania go spośród różnorodnych przekazów. Wydaje się, że im mocniejsze środki, po które sięgają nadawcy, im większy stopień kontrowersji wywołuje ich komunikat, tym bardziej zwiększa się szansa na bycie zauważonym - skomentowanym. Chodzi o wywołanie reakcji. Jakość komunikatu ma znaczenie drugorzędne wobec możliwości funkcjonowania w Sieci.

Współczesna sfera publiczna zdominowana jest przez przekazy funkcjonujące w sferze osobistej - intymne i prywatne (m.in. zjawisko celebrytów), stąd całą współczesną kulturę określa się jako kulturę obnażania w różnym znaczeniu, np. kult nagości, intymne zwierzenia itp. Można to określić mianem ekshibicjonizmu emocjonalnego, odzierania się z własnej prywatności. Coraz powszechniejsze przekonanie, że istnieje się tylko wtedy, gdy jest się znanym i widzianym, wymusza ekshibicjonistyczne zachowania i rezygnację 
z własnej intymności. We współczesnych mediach można zauważyć dominację reprezentacji seksu w publikowanych treściach, co niekiedy określa się mianem pornoszyku (porno chic). Pornoszyk przejawia się w pornografizacji niemal wszystkich wymiarów kultury. Pornografizacja oznacza nie tylko seksualizację wielu obszarów masowej kultury, ale także realne wkraczanie do niej osób związanych z branżą pornograficzną, które na swój sposób stają się popkulturowymi celebrytami.

Narcystyczne skupienie na sobie i zabieganie o uwagę innych pozbawia ludzi empatii. Według badań cytowanych przez K. Duttona (2014) współcześni studenci amerykańskiego college’u wykazują o około 40\% mniejszą empatię niż ci sprzed $20 \mathrm{czy} 30$ lat. W zastraszającym tempie rośnie też poziom zachowań narcystycznych, które mają wpływ na zanikanie empatii. Wraz z jednym, jak i drugim zjawiskiem postępuje zanik umiejętności społecznych. Być może częściowym rozwiązaniem w tej sytuacji byłoby ograniczenie korzystania przez młodych ludzi z nowych mediów oraz wprowadzenie do szkół „treningów empatii”. Narastający w przestrzeni Internetu hejt, cyberbullying, patostream może ulec modyfikacji w wyniku działania różnych organizacji, platform internetowych. Mogą pojawić się także zjawiska nowe, być może zawierające jeszcze więcej okrucieństwa i przemocy, tym bardziej że „zapotrzebowanie” na tego typu „rozrywkę” jest ogromne i wciąż rośnie, również w świecie realnym. Znane są historie nastolatków, przesiąkniętych obrazami wirtualnej przemocy i śmierci, którzy zakatowali, dotkliwie pobili, a nawet zabili rówieśnika, ponieważ bardzo chcieli zobaczyć, „jak to jest naprawdę” („Gazeta Prawna”, 2009).

\section{Podsumowanie}

Patostream jest bardzo niepokojącym zjawiskiem, rodzącym liczne zagrożenia. Jest interaktywnym wyjściem poza świat wirtualny i przeniesieniem przemocy do świata realnego, gdzie łzy, krew i poranione ciała są prawdziwe, ból, strach jest nieudawany, upojenie alkoholowe czy narkotykowe rzeczywiście prowadzi do utraty świadomości. Dlatego właśnie dla wielu świat patostreamu jest atrakcyjny. Jego ekspansji sprzyja przekonanie użytkowników o anonimowości patostreamowych przekazów, które sprawia, że nie stawiają sobie żadnych granic i nie obawiają się społecznego ostracyzmu.

Ludzie mają naturalną skłonność do podglądactwa. Mimetyzm był jednym z ważnych impulsów rozwoju, pomógł przetrwać naszemu gatunkowi, dzięki naśladownictwu i nauce nowych zachowań (Urbańska, 1997). Jednak człowiek naśladujący, pozbawiony kontroli, ze swoją pierwotną, prymitywną ciekawością, nosi w sobie ogromną, niszczącą siłę. Pierwsze talk show Mariusza Szczy- 
gła, emitowane od 1993 roku, czy Big Brother nie dorównują w najmniejszym stopniu temu, co obecnie proponuje interaktywna telewizja i Internet.

Komercyjne kanały oferują treści nasycone przemocą, agresją, wulgaryzmami, ponieważ odbiorcy domagają się wrażeń. Patostreaming rozwija się dzięki interaktywności, co pozwala każdemu na bycie "twórcą”, „artystą", który wpływa na wirtualną rzeczywistość, komentując wydarzenia. Znaczącą rolę odgrywa w nim filozofia zysku, która coraz bardziej zaciera granice między dobrem a złem. Widziany przez pryzmat pastostreamowych produkcji Internet bardziej przypomina przerażający, pełen potworów las z baśni braci Grimm niż wirtualny raj.

W teorii Carla Gustava Junga to, co zaprzeczone, wyparte z oficjalnej przestrzeni (w tym wypadku ułomność, czyli grzeszność ludzkiej natury, ludzka zdolność do okrucieństwa, realność popędu śmierci) zostaje zepchnięte do nieświadomości, sfery cienia, skąd powraca w przetworzonej - na miarę epoki - formie (Jacobi, 2014). Cień ponowoczesnej, jednocześnie globalnej i zindywidualizowanej, sprowadzonej do medialnych obrazów narcystycznej kultury może się zatem manifestować w patostreamowych produkcjach. Przeciwdziałanie narastaniu samego zjawiska oraz negatywnym konsekwencjom ekspozycji na tak patologiczne i demoralizujące treści wymaga zabiegów o charakterze interdyscyplinarnym. Przede wszystkim pogłębienia badań naukowych nie tylko nad samym fenomenem w ujęciu kulturowym, ale także nad kondycją psychiki współczesnego człowieka. Niezbędny jest powrót do filozoficznej refleksji nad złożonością ludzkiej natury, naznaczonej tendencją do czynienia zła. Przed rodzicami, wychowawcami i pedagogami staje szczególnie trudne zadanie formacji moralnej dzieci i młodzieży w dobie Internetu. Aby skutecznie bronić młode pokolenie przed obrazami bezmyślnego okrucieństwa, głupoty i obrzydliwości nie wystarczą stosowne regulacje prawne i ich egzekucja. Potrzeba takiego sposobu rozumienia siebie i świata, który pozwoli uznać realną obecność zła w człowieku i świecie oraz wziąć za nie osobistą odpowiedzialność.

Dopiero rozpoznanie i transformowanie „ciemnych” stanów u siebie oraz w grupie (rodzinnej, rówieśniczej, społeczności lokalnej, narodowej, globalnej i in.) umożliwi wkroczenie na ścieżkę prowadzącą ku wspólnemu dobru (Olchanowski, 2013, s. 237),

gdyż, jak twierdzi Zygmunt Bauman:

„jasne” i „ciemne” nurty nie dadzą się w praktyce nowoczesności [ani żadnej innej epoki - dop. P.A.] odseparować, płyną bowiem one z jednego źródła i to w taki 
sposób, że jeden bez drugiego nie popłynie i że wyschnąć mogą tylko równocześnie. Nadzieje na to, że można będzie kiedyś, z pomocą zabiegów czarodziejskich, pluskać się w nurcie „jasnym” bez ryzyka pogrążenia się w „ciemnym”, należy między bajki włożyć, wraz z pomysłami magnesu o biegunie północnym, bez południowego (Bauman, 1993, s. 126).

\section{BIBLIOGRAFIA}

Baran, M., Cichocka, E., Maranowski, P., Pander, W. (2016). Cybernauci - diagnoza wiedzy, umiejętności i kompetencji dzieci i młodzieży, rodziców i opiekunów oraz nauczycieli w zakresie bezpiecznego korzystania z Internetu. Raport podsumowujacy badanie ex-ante. Pozyskano z: https://cybernauci.edu.pl/wp-content/uploads/2016/o6/Cybernauci-diagnoza-wiedzyumiej\%C4\%99tno\%C5\%9Bci-i-kompetencji.-Raport.pdf, [data dostępu: 08.02.2020].

Barlińska, J. (2013). Młodzież w Sieci - podłoże zachowań agresywnych. W: Ł. Wojtasik (red.), Jak reagować na cyberprzemoc. Poradnik dla szkót. Warszawa: Fundacja Dzieci Niczyje.

Baron-Cohen, S. (2014). Teoria zła. O empatii i genezie okrucieństwa. Sopot: Smak Słowa.

Bauman, Z. (1992). Nowoczesność i Zagłada. Warszawa: Fundacja Kulturalna Masada.

Bauman, Z. (1993). O nowoczesności TEJ Zagłady - raz jeszcze. Kultura Współczesna, 2.

Baumeister, R.F. (2001). Evil: Inside human violence and cruelty. New York, NY: Holt Paperbacks.

Bek, D., Popiołek, M. (2019). Patostreaming - charakterystyka i prawne konteksty zjawiska. Zarzadzanie Mediami, 7(4), 247-262.

Błachnio, A. (2007). Przegląd wybranych badań nad wpływem Internetu na dobrostan psychiczny i społeczny użytkowników. Psychologia Społeczna, t. 2, 3-4 (5), 225-233.

CBOS. (2015). Dzieci i młodzież w Internecie - korzystanie i zagrożenia z perspektywy opiekunów. Pozyskano z: https://www.cbos.pl/SPISKOM.POL/2015/K_110_15.PDF, [data dostępu: 09.02.2020].

Chalier, Ph. (2017). Is gratuitous violence the characteristic of man. Pozyskano $\mathrm{z}$ : https://www. researchgate.net/publication/318858549_Is_gratuitous_violence_the_characteristic_of_ man, [data dostępu: 08.02.2020].

Cyrek, B. (2018). Czarny humor i odwrażliwienie: postawy internautów wobec kultury nadmiaru i fake newsów. Media, Kultura, Komunikacja Społeczna, t. 14, 4, 25-34.

Dutton, K. (2014). Mądrość psychopatów. Warszawa: Muza.

Eco, U. (2018). Historia brzydoty. Wyd. 6. Poznań: Rebis.

Foucault, M. (2009). Nadzorować i karać. Narodziny więzienia. Warszawa: Aletheia.

Freud, S. (1991). Wprowadzenie do narcyzmu. W: K. Pospiszyl, Zygmunt Freud. Człowiek i dzieło, (s. 273-308). Przeł. B. Kocowska, A. Czownicka, M. Albiński, L. Jekels. Wrocław-Warszawa-Kraków: Ossolineum.

Freud, S. (2001). Teoria libido i narcyzm (Wykład XXVI). W: S. Freud, Wstęp do psychoanalizy. Przeł. S. Kempnerówna, W. Zaniewicki. Warszawa: Altaya.

Fromm, E. (1996). Serce człowieka. Jego niezwykła zdolność do dobra i zła. Warszawa: PWN.

Gazeta Prawna. (2009). Zabili, bo chcieli zobaczyć jak umiera człowiek. Pozyskano z: https://www.gazetaprawna.pl/wiadomosci/artykuly/37999o,zabili-bo-chcieli-zobaczycjak-umiera-czlowiek.html,komentarze-najnowsze,1, [data dostępu: 03.05.2020].

Górka, M. (2017). Cyberbezpieczeństwo dzieci i młodzieży. Realny i wirtualny problem polityki bezpieczeństwa. Warszawa: Difin.

Groves, Ch.L., Prot, S., Anderson, C.A. (2006). Violent media effects. Theory and evidence.

W: H.S. Friedman (red.), Encyclopedia of Mental Health, (t. 4). Wyd. 2. Berkeley: Academic Press.

Horney, K. (1987). Nowe drogi w psychoanalizie. Warszawa: PWN.

Horney, K. (1999). Neurotyczna osobowość naszych czasów. Poznań: Rebis. 
Jacobi, J. (2014). Psychologia C.G. Junga. Poznań: Zysk i S-ka Wydawnictwo.

Jędrzejko, M., Morańska, D. (2014). Cyfrowi Tubylcy. Socjopedagogiczne aspekty nowych technologii cyfrowych. Warszawa: Aspra.

Katechizm Kościoła Katolickiego. (1994). Poznań: Pallotinum.

Kmieciak-Goławska, A. (2018). Patostreaming jako narzędzie popularyzacji podkultury przemocy. Biuletyn Polskiego Towarzystwa Kryminologicznego im. Prof. Stanisława Batawii (PTK), 25, 171-183.

Kim sa patostreamerzy? Historia Rafatusa. (2018). Pozyskano z: https://uwaga.tvn.pl/reportaze,2671,n/kim-sa-patostreamerzy-historia-rafatusa,257377.html, [data dostępu: 20.12.2018].

Kohut, H. (1977). Restoration of the Self. New York: Internation University Press.

Kozak, S. (2011). Patologie komunikowania w Internecie. Warszawa: Difin.

Krajewska, A. (2012). Niebezpieczeństwa szybkostrzelnej kultury obrazu w okresie dzieciństwa. Journal of Modern Science, 3, 91-107.

Lelonek-Kuleta, B. (2012). Uzależnienie od czynności - zdefiniowanie pojęcia, specyfika problemu oraz kierunki diagnozy. Serwis Informacyjny NARKOMANIA, 1(57), 13-18.

Mellibruda, J., Sobolewska-Melibruda, Z. (2011). Integracyjna psychoterapia uzależnień. Teoria i praktyka. Wyd. 2. Warszawa: IPZ PTP.

Miller, A.G. (red). (2008). Dobro i zło z perspektywy psychologii społecznej. Kraków: WAM.

Ministerstwo Cyfryzacji. (2019). Edukacja przede wszystkim, czyli jak walczyć ze zjawiskiem patostreamów. Pozyskano z: https://www.gov.pl/web/cyfryzacja/edukacja-przede-wszystkim-czyli-jak-walczyc-ze-zjawiskiem-patostreamow, [data dostępu: 09.02.2020].

Moore, J.J. (2019). Powiesić, wybebeszyć, poćwiartować, czyli historia egzekucji. Kraków: Społeczny Instytut Wydawniczy Znak.

NIK. (2017). Zapobieganie i przeciwdziałanie cyberprzemocy wśród dzieci i młodzieży. Pozyskano z: https://www.nik.gov.pl/plik/id,15249,vp,17730.pdf, [data dostępu: 08.02.2020].

Olchanowski, T. (2013). Pedagogika a paradygmat nieświadomości. Warszawa: Eneteia.

Perry, G. (2018). The evil inside us all. New Scientist, t. 240 (3199), 39-41.

Płatek, P.P. (2017). Wpływ Internetu na rozwój człowieka w refleksji semantyczno-kulturowej. Warszawskie Studia Pastoralne UKSW, 2 (35), 155-186.

Polak, M. (2009). Cyfrowi imigranci i tubylcy, czyli spróbujmy zintegrować dwa światy w polskiej szkole. Prezentacja multimedialna. Pozyskano z: www.slideshare.net/edunews/cyfrowi-tubylcy-i -imigranci, [data dostępu: 30.12.2018].

Popularny Gural zatrzymany. Policja zajęła się patologia na Youtube. Pozyskano z: https:// www.wprost.pl/zycie/10114610/popularny-gural-zatrzymany-policja-zajela-sie-patologia -na -youtube.html, [data dostępu: 21.12.2018].

Prensky, M. (2001). Digital Natives. Digital Immigrants. Pozyskano z: www.marcprensky.com/ writing/Prensky\%20-\%2oDigital\%2oNatives,\%2oDigital\%2oImmigrants\%20-\%20Part1. pdf, [data dostępu: 11.02.2019].

Pyżalski, J. (2012). Agresja elektroniczna i cyberbullying jako nowe ryzykowne zachowania młodzieży. Kraków: Oficyna Wydawnicza Impuls.

Siedlanowski, P. (2018). Homo crudelis? Patostream - kolejna patologia w sieci. Biuletyn Edukacji Medialnej, 2.

Sofsky, W. (1999). Traktat o przemocy. Wrocław: Wydawnictwo Dolnośląskie.

Spitzer, M. (2013). Cyfrowa demencja. W jaki sposób pozbawiamy rozumu siebie i swoje dzieci? Warszawa: Dobra Literatura.

Suchodolska, M. (2018). Gural, Rafonix, Rafatus, Daniel Magical, czyli podgladanie patologii na YouTubie. Przemoc, pijaństwo i defekacja na żywo. Pozyskano z: https://technologia. dziennik.pl/internet/artykuly/573748,gural-rafonix-rafatus-daniel-magical-youtube-patostreamerzy.html, [data dostępu: 08.02.2020].

Szpunar, M. (2016). Kultura cyfrowego narcyzmu. Kraków: AGH. 
Tanaś, M. (red.). (2016). Nastolatki wobec Internetu. Raport NASK. Pozyskano z: https://akademia.nask.pl/publikacje/Nastolatki_wobec_internetu_.pdf, [data dostępu: 08.02.2020].

Urbańska, A. (1997). Koncepcja mimesis René Girarda. Etnografia Polska, t. XLI, 1-2, 21-45.

Walendzik, G., Wilkosz, K. (2018). Zapobieganie i przeciwdziałanie przemocy w cyberprzestrzeni. Ochrona dzieci i młodzieży. Kontrola Państwowa, t. 63, 1 (63), 51-69.

Wierciński, J. (2019). Wyroki więzienia dla patostreamerów $z$ Gdańska za transmisję na żywo $z$ pobicia 58-letniego sasiada. Pozyskano z: https://dziennikbaltycki.pl/wyroki-wiezieniadla-patostreamerow-z-gdanska-za-transmisje-na-zywo-z-pobicia-58letniego-sasiada/ar/ c1-14140439, [data dostępu: 08.02.2020].

Wojtyna, M. (2019). Nuda, dymy, podmiotowość. Patostream jako gatunek. Tekstualia. Palimpsesty Literackie, Artystyczne, Naukowe, 5 (58), 55-70.

\section{SUMMARY}

\section{Homo crudelis in the era of Internet}

Common access to the Internet is strictly correlated with increased number of pathological activities in the Web. The paper presents the patho-streaming phenomenon - online live emissions of demoralized behaviours and verbal and physical aggression acts with the purpose of gaining popularity measured by the number of viewers as well as financial benefits. Pathostream is presented from historical perspective as an answer to the eternal demand for cruelty and also as a symptom of exhibitionism and narcissism in mass media culture.

KEYWORDS: Internet, pathostreaming, cruelty, exhibitionism, narcissism 